\title{
ASTEROIDS EXPLORATION WITH BALDONE SCHMIDT TELESCOPE
}

\author{
I.Eglitis \\ Institute of Astronomy of the University of Latvia, \\ Riga, Latvia, ilgmars.eglitis@lu.lv
}

\begin{abstract}
CCD observations of asteroids were obtained in 2008 with the Baldone Schmidt telescope (aperture $/$ diameter/focal length $=80 / 120 / 240 \mathrm{~cm}$ ) at the Baldone Astrophysical observatory (code 069) of the Institute of Astronomy of the University of Latvia. The methodology of monitoring of asteroids and orbit calculations are described. In the Minor Planet Circulars and the Minor Planet Electronic Circulars 5434 astrometric positions of 1488 asteroids were published. Among them, 76 asteroids of different type were newly discovered at Baldone Observatory. Twelve asteroids were named.
\end{abstract}

Baldone Schmidt telescope optical system was improved by inserting an additional optical system in the telescope, forming a flat telescope focal surface that coincides with the surface of the flat beam receiver. Two large (4096 x 4096 pixels) CCD cameras are now installed on the plate holder of the telescope. They cover two square degrees of the sky.

The digitizing of the Baldone Schmidt archive began in 2012. The processing results of 152 plates obtained in $U$, B, V, R bands in 1967-1996 were used to search for images of small bodies of the Solar system. Images were processed using advanced complex LINUX / MIDAS / ROMAPHOT programs updated in the Main Observatory of National Academy of Sciences of Ukraine. 57 asteroids and 2 comets (31P/Schwassmann-Wachmann 2, C/1969 T1 (Tago-Sato-Kosaka)) were identified on these plates. Overall 87 positions of asteroids of different types and 2 positions of comets were measured. These objects cover magnitude range from 9.8 to 17.1 .

Keywords: Asteroids, Schmidt camera, plates archive

АБСТРАКТ. ПЗЗ-спостереження астероїдів були отримані в 2008 році за допомогою телескопа системи Шмідта в Балдоне (діафрагма/діаметр/фокусна відстань $=80 / 120 / 240$ см) на Астрофізичній обсерваторії Балдоне (код 069) Інституту астрономії Латвійського університету. Описано методологію моніторингу астероїдів та обчислень їх орбіт. В циркулярах "Малі планети" та в електронних циркулярах "Малі планети" опубліковано 5434 астрометричних позицій для 1488 астероїдів. Серед них в обсерваторії Балдоне було відкрито 76 астероїдів різного типу. Дванадцять астероїдів отримали назви.

Оптична система телескопа Шмідта в Балдоне була вдосконалена введенням додаткової оптичної системи для створення плоскої фокальної поверхні, яка збігається з плоскою поверхнею приймача. Дві великі (4096x4096 пікселів) ПЗ3-камери встановлені на тримачці телескопа. Вони покривають поле неба у два квадратні градуси.

Оцифрування архіву телескопа Шмідта в Балдоне розпочалося в 2012 році. Результати обробки 152 фотоплатівок, отриманих в смугах U, B, V, R в 1967-1996 роках, були використані для пошуку зображень малих тіл Сонячної системи. Зображення були оброблені за допомогою сучасних програм LINUX/MIDAS/ ROМАРНОТ, вдосконалених в Головній астрономічній обсерваторії Національної академії наук України. На цих платівках було знайдено 57 астероїдів та 2 комети (31P/Schwassmann-Wachmann 2, C/1969 T1 (Tago-SatoKosaka)). Всього було проміряно 87 позицій для астероїдів різних типів і 2 позиції комет. Ці об'єкти покривають діапазон від 9,8 до 17,1 зоряної величини.

Ключові слова: астероїди, камера Шмідта, архів фотоплатівок

\section{Introduction}

The surfaces of smallest planets and moons of the Solar system are covered with large number of craters created by asteroids. Every day, Earth is bombarded with more than 100 tons of dust and millimeter- sized particles from space. About once a year, a two meter sized asteroid hits Earth's atmosphere, often creating a bolide event as the friction of Earth's atmosphere causes disintegration of it sometimes explosively. Chelyabinsk type event takes part about every five years. The largest impact during the last 20-year interval was the recent daytime Chelyabinsk event $(440,000-500,000$ tons of TNT) recorded over central Russia on February 15, 2013. This small asteroid that exploded in the atmosphere near Chelyabinsk, Russia was about 16 meters in size before it hit the Earth. While that impact focused public attention on the potential hazards of NEO impacts with Earth, space scientists have long known that such events are just a part of Earth's geologic history. The larger trails of asteroid falls still can be found on the Earth, e.g. 4000 year-old Kali crater in Estonia on Saaremaa island, 50000 year old Arizona crater near Winslow in the USA, etc. Many of small impacts similar to Chelyabinsk are unknown because they happened in regions with no inhabitants - Siberia, Amazon jungles, oceans and deserts. The radar observations reveal that asteroids similar to Chelyabinsk event hit the Earth on 
average every 5 years. With radar observations it is possible to detect small asteroids that are disintegrated in the Earth's atmosphere (Planetary Science). Scientific assessments of the risk, as well as the hazards posed by future asteroid impacts with Earth vary. In an article published in "Nature" Brown (2013) and his colleagues reported that "telescopic surveys have only discovered about 500 near-Earth asteroids that are 10-20 meters in diameter (comparable to the Chelyabinsk asteroid) of an estimated near-Earth asteroid population of around 20 million, implying that a significant impactor population at these sizes could be present but not yet cataloged in the discovered near-Earth asteroid population". The importance of such research of asteroids is proved by the fact, that the largest known celestial threat to the Earth within the period after Christ was the $320 \mathrm{~m}$ large asteroid Apophis which was discovered only in June 2004. This fact and the yearly discoveries of a large number of new NEO type asteroids show how little attention has been given to the studies of the small bodies in the Solar system so far. The importance of the small body studies in the Solar system can be properly evaluated if we recall the volcanic eruption effects in Iceland, comparable to the effect caused by the fall of a small asteroid. The fall of an asteroid larger than $50 \mathrm{~m}$ will be a disaster that can stop the progress in the world for several years, but the fall of a $300 \mathrm{~m}$ and larger body can terminate the development of civilization on the Earth for several decades, or even destroy the humanity at all. At the 5th meeting of the PECS Committee on 27th of May 2009 in Esrin (Italy), the total number of NEO and hazard asteroids, measures to 66000 (Bobrinsky, 2009). Successful results were achieved on monitoring systems such as Pan-STARRS, Catalina Sky Survey, Mt. Lemmon Surway, Kitt Peak-Spacewatch, LINEAR, and some space missions such as WISE monitoring asteroids. Despite that, the current progress is not fast enough. Catalogue of NEO listed 17791 hazard objects on February 2018 (Minor Planet Center, 2018) or $27 \%$ of all hazard objects. NASA congress on 5th of March 2007 provided an assessment of the problem in Near-Earth Object Survey and Deflection Analysis of Alternatives. It concluded that only a wide ground base plus space sensor observations of Venus, like the orbit, can allow a more prompt solution of the problem, i.e. to discover the NEO asteroids in the nearest future (Milani et al., 2013).

Finally, the research of asteroids manages to draw vast attention of mass media, thus promoting an awareness of the importance of science, including astronomy, among public at large, young people in particular. From the other point of view the investigation of asteroids properties are important for development of evolution theory of the Solar system and classification of small objects in the Solar system. From photometric study of light curves an additional information can be obtained about size, rotation period, structure of objects, existence of craters and ice fields on the surface, which is very important data for space missions and for fantastic ideas about mineral mining on asteroids. The spectral observations can give information about chemical composition of asteroids and comets.

\section{Asteroid obsevations}

The Baldone Schmidt system telescope was launched in 1966 at Riekstukalns observation site of the Institute of Astronomy, the University of Latvia (the Radio Astrophysical observatory of Latvian Acad. Sci. until 2001) near Baldone. The diameter of the correction plate of the telescope is $800 \mathrm{~mm}$, the diameter of the main mirror $1200 \mathrm{~mm}$. The main mirror is mounted at a distance of $4780 \mathrm{~mm}$ from the correction plate. The reflecting surface of the mirror was restored in 2005. The image, which covers $4046^{\prime}$ of sky diameter, appears on the spherical surface of the main focus with a bend radius of $2400 \mathrm{~mm}$.

The asteroid project of the Baldone Observatory (IAU code 069 , longitude $24.4041 \mathrm{E}$, latitude $56.7734 \mathrm{~N}$, altitude $103 \mathrm{~m}$ ) includes astrometric and photometric observations of asteroids and the newly discovered Near Earth Objects (NEOs), including their monitoring. Astrometric CCD observations of asteroids at the Baldone Observatory were started in January of 2008, using the Schmidt telescope with a ST-10XME CCD camera (field of view 21' $\times$ 14'). The first three new asteroids were discovered in January of 2008 (2008AL86, 2008AU101 and 2008AV101). Two exceptional objects have been discovered: the Apollo-type NEO 2008OS9 (Cernis \& Eglitis, 2008), a Centaur-type asteroid 2009HW77 (Cernis \& Eglitis, 2009) and two Trojan group asteroids (2011 QA50 with $\mathrm{a}=5.27 \mathrm{au}$ and $2013 \mathrm{RO} 26$ with $\mathrm{a}=5.12 \mathrm{au})$. The limiting $\mathrm{R}$ magnitude for the Baldone Schmidt telescope is about 21 for unfiltered CCD images with an exposure time of about 8 minutes. All astrometric measurements and reductions were done using Astrometrica software (Raab, 2003) and pipeline program SkySift (Holvercem, 2018). SkySift was intensely used for research in fields with high density of stars. Reference stars were selected from the catalogs USNO-A2.0, USNO-B1.0, UCAC-2 and UCAC4. Most of asteroids were discovered in the morning sky about 15-20 days before their opposition time at 150-160 deg elongations. The sky survey has been done close to the ecliptic (mostly no more than $10 \mathrm{deg}$ from the ecliptic line), taking three (or sometimes four) CCD images from the same field, with 20-30 min time spans between exposures. The Baldone Schmidt telescope is very useful for searching new asteroids and doing follow-up astrometry of poorly observed NEOs and unusual objects. During 2008-2013, 2117 CCD images (using 116 observing nights) for astrometry of asteroids and comets were obtained by I. Eglitis. K. Cernis (Institute of Astronomy, Vilnius University) have processsed CCD images for new objects and measured positions of all asteroids appearing in the CCD frames. 3511 astrometric observations of 826 asteroids, including at least 5 NEOs, were published in the Minor Planet Circulars (MPC) and Minor Planet Electronic Circulars (MPEC). But during 2016-2018, 12587 CCD images (using 68 observing nights) for astrometry of asteroids and comets were obtained. 4395 astrometric observations of 1465 asteroids were published in the MPC. Till now, 2018 October, the credits for discovery of 34 asteroids have been received by the Baldone Observatory from the Minor Planet Center. 12 of them have been named (see Table 1). Our contribution is about $0.012 \%$ of all of the $55.7 \times 10^{6}$ observations of asteroids done during 
this period in the world. The newly discovered (76) compose a similar part, $0.015 \%$, of all 523800 aster-oids discovered. In this period a great numbers of aster-oids was discovered by the specialized projects: LONEOS, LINEAR, Spacewatch, Catalina and Panstarrs.

\section{Badone Schmidt telescope optical system devel- opment}

Schmidt telescopes are used to produce high quality large field star images, which in many ways outweigh all other telescopes with similar aperture diameters. These telescopes are no longer used in world, due to the technological transition to electronic sensors for the purpose of capturing the space images. Schmidt cameras have very strongly curved focal planes, thus requiring for detector to be correspondingly curved. When transitioning to a new type of image object acquisition - from photography to the use of video sensors, we encounter an unresolved problem, - how to match the curved large scale telescope's focal surface with the surface of a flat light imaging sen-sor.

The team of the Institute of the Astronomy has succeeded in designing a small optical circuitry that would improve the Baldone Schmidt optical system. Small lens combination is inserted in the telescope forming a flat telescope focal surface which coincides with the surface of the flat-beam receiver. This lens combination is positioned before two SBIG CCD cameras STX-16803. This optical system upgrade makes it possible to use the existing large-field flat-panel video sensors without loss of quality, at relatively low cost and without the expensive Schmidt telescope reconstruction. SBIG STX-16803 CCD camera has KAF-16803 4096x4096 pixels Monochrome Sensor with size $36 \times 36 \mathrm{~mm}$. The size of one pixel is $9 \times$ 9 micron.

We have created Schmidt telescope with an upgraded optical system. To establish how they work together, basic technological components are integrated into the main focal plane of Baldone Schmidt telescope. There are two STX -16803 cameras that are positioned on cassette holder position. Both cameras cover two square degrees of the sky.

\section{Digitizing of Baldone Schmidt telescope archive}

The regular digitization and processing of photographic astroplates was started in Baldone observatory from 2013. The photos were digitized using Epson Expression 10000XL and 11000XL commercial scanners with 1200 dpi (or 2400 dpi) resolution. For processing purposes all images were transformed from TIFF format to the FITS format with an original program created at the Institute of Astronomy. Till this moment more than 18000 (from 22000) direct photos have been digitized. Scans are stored on the server of the University of Latvia

The digitizing of the UV-part of Baldone collection started in June 2016 with two EPSON EXPRESSION 10000XL and three 11000XL flatbed scanners. Its photometric and astrometric characteristics were previously tested, and the optimum mode of scanning was found (Protsyuk et al., 2014). Images were processed using ad- vanced LINUX / MIDAS / ROMAPHOT programs (Andruk, 2015). The software was developed and implemented in Main Astronomical Observatory of the National Academy Science of Ukraine to process the digitized astronomic photos as well as to obtain astrometric coordinates and photometric magnitudes of stars and compact galaxies.

In order to investigate variability of stars within time span from 1967 to 2005, many of the sky regions have been photographed tens and some of them even hundreds of times.

In addition to the main tasks, digitized photos of star fields allows to carry out a massive search for images of small bodies of the solar system and to determine their coordinates. From the observations of earlier epoch it is possible to extract information about the locations of these bodies (Eglitis et al., 2016).

\section{Results}

During the sky survey of the ecliptic, 76 new asteroids were discovered in 2008-2018: 43 of them have multipleapparition orbits, 9 are one opposition objects from which 7 have no orbit.

The first successful observations with upgraded Baldone Schmidt telescope were made in August-September 2017. The quality of the images is high. Four plates obtained at different declinations (from 2 degrees till 60 degrees) with $60 \mathrm{sec}$ exposures were measured. The results of diameter measurements of different magnitude stars de show that diameters of 17 th magnitude stars do not exceed six pixels in the center and four pixels in corners of the images.

The processing results of 152 observations of clusters and Pluto in UBVR bands from 1967 to 1996 were used for broad search for images of small bodies of the Solar sys-tem. As a result, 57 asteroids and 2 comets (31P/Schwassmann-Wachmann 2, C/1969 T1 (Tago-SatoKosaka)) were identified on these plates. From them 87 positions of asteroids and 2 positions of comets were received. These objects cover a magnitude range of 9.8 to 17.1. Their orbit types are: Main Belts, Apollo, Centaur, Trojan, Hungarias and Mars-crosser.

\section{Conclusion}

The project, together with other observatories and space missions, will contribute to plan cataloging of NEOtype and Earth-hazard objects of at least 90\% till 2021. The project will complement observations of asteroid positions that are missing to accurately determine orbital elements. The research results will be sent to the Minor Planet Center, which operates at the Smithsonian Observatory and are published in Minor Planet Circulars. The results of calculations of orbital elements were compiled in 3 papers, which are included in the Web of Science database. It is important to analyze the chemical composition of asteroids from the point of view of evolution and practical applications. The planned multicolor photometric and low-resolution spectral observations will allow classification of asteroids - the division of C-type (carbonaceous), S-type (silicate) and M-type (metallic). The resulting light 
curves will allow not only to determine the rotation period of small bodies, but also to design an asteroid model by shape. On the other hand, the rapid changes in light curves over the main change in the brightness make it possible to predict the existence of large deep craters on the surface (in the case of a sharp drop in brightness) or the areas of ice fields on the surface (in the case of rapid increase of brightness). All of these asteroid characteristics are important for evaluating the albedo, modelling the form and detecting the sizes of objects. Asteroid rotation calculations are important for planning space missions for their direct exploration and also for mining them in the future.

The efficiency of the new optical system is obvious. In August-September 2017 after improvement of the optical system, 21 new asteroids were discovered. In the previous years $(2008-2015)$, using one small $(10 \times 15 \mathrm{~mm})$ SBIG CCD ST-10XME, only 49 new asteroids were discovered (Cernis et al., 2015). In the Autumn 2018 seven new discoveries were added.

Asteroids with high accuracy of up to 16-17 magnitudes can be detected on the photographic plates of Baldone Observatory. Among those may be objects which are discovered much later than observed. The presence of the archive of all observations in time scale 1966-2002 will give the possibility to sort and analyze the asteroids of interest, including the bright Kuiper Belt objects.

According to data analysis, the rms-error of measurements of coordinates increases from 0.10 to 0.25 arcsec by increas-ing asteroid's magnitude from 13 to 16 . (Eglitis et al., 2016).

Acknowledgements. This investigation is supported by project Nr. lzp-2018/1-0401 „Complex investigations of Solar System small bodies".

\section{References}

Andruk V.M., Pakuliak L.K., Golovnya V.V. et al.: 2015, arxiv.org/abs/1512.05535.

Bobrinsky N.: 2009, The European SSA Preparatory Programme. 5th meeting of the PECS committee, ESRIN, Italy. [online]: http://esamultimedia.esa.int/multimedia/ esoc/opsg/opsg_forum_ssa_05122008.ppt

Brown P.G., Assink J.D., Astiz L. et al.: 2013, Nature, 503, 238.

Cernis K., Eglitis I.: 2008, Minor Planet Electronic Cirrcular, 2008-O66.

Cernis K., Eglitis I.: 2009, Minor Planet Electronic Cirrcular, 2009-U68.

Cernis K., Wlodarczyk I., Eglitis I.: 2015, Baltic Astronomy, 24, 251.

Eglitis I., Eglite M., Shatokhina S.V. et al.: 2016, Odessa Astron. Publ., 29, 123.

Holvercem P.: 2018, SkySift [online]: http://sites.mpc.com.br/holvorcem/
Table 1: Named asteroids discovered in Baldone observatory

\begin{tabular}{|l|l|l|l|l|}
\hline Number & Label & Name & $\begin{array}{l}\text { Named } \\
\text { year }\end{array}$ & $\begin{array}{l}\text { Diame- } \\
\text { ter }\end{array}$ \\
\hline 274084 & $\begin{array}{l}2008 \\
\text { AU101 }\end{array}$ & Baldone & 2011 & 1,5 \\
\hline 284984 & $\begin{array}{l}2010 \\
\text { GC158 }\end{array}$ & Ikaunieks & 2012 & 1,5 \\
\hline 294664 & $\begin{array}{l}2008 \\
\text { AL86 }\end{array}$ & Trakai & 2012 & 3,5 \\
\hline 321324 & $\begin{array}{l}2009 \\
\text { HJ68 }\end{array}$ & Vytautas & 2012 & 3 \\
\hline 330836 & $\begin{array}{l}2009 \\
\text { HW77 }\end{array}$ & Orius & 2013 & 35 \\
\hline 343157 & $\begin{array}{l}2009 \\
\text { HH68 }\end{array}$ & Mindaugas & 2013 & 3,5 \\
\hline 392142 & $\begin{array}{l}2009 \\
\text { HV19 }\end{array}$ & Solheim & 2014 & 3 \\
\hline 332530 & $\begin{array}{l}2008 \\
\text { OS18 }\end{array}$ & Canders & 2015 & 2 \\
\hline 352646 & $\begin{array}{l}2008 \\
\text { OZ1 }\end{array}$ & Blumbahs & 2015 & 1,5 \\
\hline 418220 & $\begin{array}{l}2008 \\
\text { CL177 }\end{array}$ & Kestutis & 2016 & 1 \\
\hline 428694 & $\begin{array}{l}2008 \\
\text { OS9 }\end{array}$ & Saule & 2016 & 0.7 \\
\hline 457743 & $\begin{array}{l}2009 \\
\text { HW20 }\end{array}$ & Balklavs & 2017 & 1 \\
\hline & & & \\
\hline
\end{tabular}

Milani A., un c.: 2013, International BELISSIMA conference, Belgrade, Romania [online]: https://www.researchgate.net/profile/Ivana_Milic_Zitni k/publication/308969745_CCD_OBSERVATTIONS_OF ERS_WITH_THE_60_cm_TELESCOPE_AT_ASV/li $\overline{\mathrm{nks}} / 5 \overline{\mathrm{fb}} 9 \mathrm{c} 96 \overline{0} 8 \mathrm{ae} 8 \overline{\mathrm{da}} \mathrm{3ce} 60 \mathrm{f} \mathrm{d} 5 \mathrm{f} / \mathrm{CCD}-$ OBSERVATIONS-OF-ERS-WITH-THE-60-cmTELESCOPE-AT-ASV.pdf

Minor Planet Center: 2018 [online]: https://www.minorplanetcenter.net/db_search/show_by neo_type?utf8 $=\% \mathrm{E} 2 \% 9 \mathrm{C} \% 93 \&$ neo_type $=$ neo

Protsyuk Yu.I., Andruk V.N., Muminov M.M. et al.: 2014, Odessa Astron. Publ., 27, 59.

Planetary Science [online]: https://www.nasa.gov/jpl/bolide-events-1994-2013

Raab H.: 2003, Astrometrica [online]: http://www.astrometrica.at/ (electronic version) 